Int. J. Morphol.,

$34(1): 205-211,2016$

\title{
Hippocampal Neuronal Apoptosis in Rat Offspring Due to Gestational Diabetes
}

\author{
Apoptosis Neuronal del Hipocampo en Crías de Ratas Debido a la Diabetes Gestacional
}

\author{
Soraya Ghafari*; Ebrahim Asadi**; Ronak Shabani***\& Mohammad Jafar Golalipour ${ }^{* * * *}$
}

GHAFARI, S.; ASADI, E.; SHABANI, R. \& GOLALIPOUR, M. J. Hippocampal neuronal apoptosis in rat offspring due to gestational diabetes. Int. J. Morphol., 34(1):205-211, 2016.

SUMMARY: Gestational diabetes mellitus (GDM) defined as impaired glucose tolerance affects approximately $6 \%$ of all pregnant women who have never before had diabetes, but who do have high blood glucose levels during pregnancy. This study was done to evaluate the apoptosis in the neuronal cells in the CA1, CA2 and CA3 subfields of hippocampus and dentate gyrus in offspring of gestational diabetes at the 7,21 and $28 \mathrm{~d}$ in postnatal rats. Thirty Wistar rat dams were randomly allocated in control and diabetic group. Dams in diabetic group were received $40 \mathrm{mg} / \mathrm{kg} / \mathrm{BW}$ of streptozotocin at the first day of gestation and control groups received an equivalent volume normal saline injection intraperitoneally (IP). Six offspring of GDM and control dams, at the 7, 21, 28 postnatal day were randomly were sacrificed quickly with anesthesia. The coronal sections of brain serially collected. The apoptosis neurons were evaluated with TUNEL Assay. In the CA1, the number of apoptotic cells in 7, 21 and $28 \mathrm{~d}$ of postnatal life were significantly increased in GDM compared to controls $(\mathrm{P}<0.001)$. In the CA2, CA3 the number of apoptotic cells in 7, 21 and $28 \mathrm{~d}$ age-old offspring were significantly increased in GDM compared to controls $(\mathrm{P}<0.001)$. In the dentate gyrus, the number of apoptotic cells in 7,21 and $28 \mathrm{~d}$ of postnatal life were significantly increased in GDM compared to controls $(\mathrm{P}<0.01)$. This study showed that the uncontrolled gestational diabetes significantly increases neuronal apoptosis in hippocampal and dentate gyrus in rat offspring.

KEY WORDS: Gestational diabetes; Hippocampus; Neuron; Apoptosis; TUNEL Assay; Dentate gyrus; Rat.

\section{INTRODUCTION}

Diabetes mellitus has increased in recent decades and is affecting almost $6 \%$ of the world's population (Hwang et $a l ., 2008)$ and regardless of its type, is associated with cerebral alterations in both human and animal models of the disease (Biessels et al., 2002; Gispen \& Biessels, 2000; McCall, 1992).

The hippocampus is a particularly vulnerable and sensitive region of the brain that is very important for declarative and spatial learning and memory (Artola, 2008).

Process of neurogenesis including cell proliferation, survival, migration and differentiation continues in the hippocampal formation well into adulthood in animals and humans (Cameron \& Gould, 1994; Gould et al., 2000; Gould \& Gross, 2002; Gould \& Tanapat, 1997; Jackson-Guilford et al., 2000).
Hippocampal neurons are also sensitive to the effects of diabetes (Gispen \& Biessels; Magariños \& McEwen, 2000) and often show damage to presynaptic and postsynaptic structures, dysregulation of calcium homeostasis, neuronal loss, dendriticatrophy in CA3 neurons, reduced expression of insulin growth factors and their receptors, and decreased neurogenesis (Jackson-Guilford et al.; Magariños \& McEwen; Li et al., 2002a, 2002b; Klein \& Waxman, 2003; Saravia et al., 2002).

Neural progenitors in the dentate gyrus (DG) proliferate, migrate and differentiate into granule cells, which extend their axons and contact the CA3 pyramidal neurons, becoming integrated into the hippocampal circuitry (Hwang et al.). In the dentate gyrus of mammals, including humans, new neurons have been shown to be generated during postnatal and adult periods (Kamal et al., 2000).

* Department of Anatomical Sciences, Golestan University of Medical Sciences, Gorgan, Iran.

** PhD student of Reproductive Biology, Department of anatomical sciences, School of medicine, Tehran University of Medical Sciences, Tehran, Iran.

*** $\mathrm{PhD}$ student of Anatomical Sciences, Department of anatomical sciences, School of Medicine, Iran University of Medical Sciences, Tehran, Iran.

***** Professor, Gorgan Congenital Malformations Research Center, Department of Anatomical Sciences, Golestan University of Medical Sciences, Gorgan, Iran. 
Diabetes mellitus may induce functional and structural changes in the brain. In addition to the diabetic condition itself, secondary complications involve brain (Lim et al., 2002).

Several factors such as enriched environments, learning, seizure, N-methyl-D-aspartate (NMDA) receptor antagonists, serotonin, and physical exercise, and ischemia enhance the proliferation of granular cell precursors and/or neurogenesis in the dentate gyrus while adrenal steroids, opioid peptides, and stress inhibit it (Kim et al., 2003).

Gestational diabetes mellitus (GDM) defined as impaired glucose tolerance affects approximately $6 \%$ of all pregnant women who have never before had diabetes, but who do have high blood glucose levels during pregnancy (Hwang et al.).

Studies have shown that diabetes type 1 and 2 reduced neurons in hippocampal and dentate gyrus. By induction of apoptosis (Jackson-Guilford et al.; Li et al., 2002a, 2002b; Klein \& Waxman; Ahmadpour \& Haghir, 2011; Ahmadpour et al., 2008, 2010; Britton et al., 2003; Gao \& Gao, 2007; Grillo et al., 2005; Li et al., 2002a, 2002b; Revsin et al., 2005).

Our previous study has shown that gestational diabetes mellitus reduced neural cell in CA1 and CA3 subfields of hippocampus in the offspring rats (Golalipour et al., 2012).

Several possible mechanisms are explained about cerebral alterations including neuronal loss due to hyperglycemia (Klein \& Waxman). The reduction of neuronal density of dentate gyrus is reported can be due to program cell death or block of neurogenesis (JacksonGuilford et al.).

Therefore, this study was done to evaluate the apoptosis of neuronal cell in the CA1, CA2 and CA3 of hippocampus and dentate gyrus in offspring of gestational diabetes at the 7,21 and $28 \mathrm{~d}$ in postnatal rats using TUNEL Assay.

\section{MATERIAL AND METHOD}

This experimental study was performed at the GolestanUniversity of Medical Sciences, Gorgan, Iran. Guidelines on the care and use of laboratory animals and approval of the ethics committee of Golestan University of Medical Sciences were obtained before the study.
Experimental animals. Wistar rats, weighing 180-220 g (12 weeks old) were used in this study. The animals were maintained in a climate-controlled room under a 12-hour alternating light/dark cycle, $20^{\circ} \mathrm{C}$ to $22^{\circ} \mathrm{C}$ temperature, and $50 \%$ to $55 \%$ relative humidity. Dry food pellets and water were provided ad libitum.

Drug. Streptozotocin (STZ) (Sigma, St. Louis, MO, USA) dissolved in sterile saline solution $(0.85 \%)$ at $40 \mathrm{mg} / \mathrm{kg}$ dose intraperitoneally injected to female rats.

Animals and experimental design. After 2 weeks of acclimation to the diet and the environment, female Wistar rats were placed with a proven breeder male overnight for breeding. Vaginal smears were done the next morning to check for the presence of sperm. Once sperm was detected that day was assigned as gestational day 1 (GD). On day 1 of gestation, pregnant females randomly allocated into the two control and diabetic groups.

Five female rats in diabetic group receiving $40 \mathrm{mg} /$ $\mathrm{kg}$ body weight of streptozotocin (STZ) and control groups (five rats) receiving an equivalent volume normal saline injection intraperitoneally (IP). Blood was sampled from the tail at 1 week after STZ injection. The mothers with blood glucose level 120-250 mg/dL known as gestational diabetic mothers. The pregnancy of dams was terminated physiologically.

Blood glucose measurements. Blood glucose level of mothers (before mating and after STZ injection) and offspring was obtained via tail vein and was estimated with a glucometer (ACCU-CHEK $®$ Active Glucometer, Roche Diagnostics, Mannheim, Germany).

Tissue collection and processing. Six offspring of GDM and control dams, at postnatal days 7, 21 and 28 (P7, P21, P28) were randomly selected and were scarified. For preparations brain was fixed in $4 \%$ paraformaldehyde in PBS for histological procedure. The coronal sections (6 micrometer) serially collected from bregma $-3.30 \mathrm{~mm}$ to $6.04 \mathrm{~mm}$ of the hippocampus (Paxinos \& Watson, 1998).

The apoptosis neurons were evaluated with TUNEL Assay.

\section{Morphometric techniques}

Terminal transferased UTP nick-end labeling (TUNEL) techniques. The whole-mounted brain stained with the terminal transferased UTP nick-end labeling (TUNEL) reaction to detect apoptosis (in situ cell death detection kit; fluorescence; Roche, Mannheim, Germany) according to the 
manufacturer's instructions. Tissue slices were pre-treated with proteinase $\mathrm{K}(10 \mathrm{mg} / \mathrm{mL})$ in $0.05 \mathrm{M}$ Tris- $\mathrm{HCl}$ buffer, $\mathrm{pH} 7.4$, washed in phosphate-buffered saline (PBS), then labeled with TUNEL reaction mixture.

Nuclear DNA fragmentation were analyzed under a fluorescence microscope (Olympus BX51, Japan) and camera DP72 using an excitation wavelength in the range of $450-500 \mathrm{~nm}$, and detection was in the range 515-565 $\mathrm{nm}$ (green). The number of TUNEL- nuclei was counted in $10000 \mathrm{~mm}^{2}$ area of the CA1, CA2 and CA3 subfield of hippocampus and dentate gyrus in 400X magnification using OLYSIA Autobioreport software (Olympus Optical, Co. LTD, Tokyo, Japan).

Statistical analysis. The TUNEL expression indices were expressed as the mean \pm SEM. Statistical analysis was based on the Student's test using SPSS v.16.0. Significance was taken as $\mathrm{P}<0.05$.

\section{RESULTS}

Apoptosis was assessed using the in situ DNA $3 \not$ end labeling assay and was apparent in the nuclei of the CA1, CA2, CA3 and DG in the diabetic and control offspring (Fig. 1).

Table III. The density of apoptotic cells in hippocampal formation of gestational diabetic and control at 28 postnatal days in the rat offspring.

\begin{tabular}{lcc}
\hline \multirow{2}{*}{ Hippoca mpal formations } & \multicolumn{2}{c}{ P7 } \\
\cline { 2 - 3 } & Control & GD \\
\hline CA1 & $12.83 \pm 1.3$ & $36.81 \pm 1.4$ \\
CA2 & $10.50 \pm 0.4$ & $25.85 \pm 1.6$ \\
CA3 & $14.16 \pm 2.1$ & $40.36 \pm 1.5$ \\
Dentate gyrus & $19.33 \pm 3.1$ & $42.18 \pm 3.6$ \\
\hline
\end{tabular}

Results are expressed as Mean \pm SEM of the mean (*compared with control group, $\mathrm{P}<0.01, \mathrm{n}=6)$.

Table II. The density of apoptotic cells in hippocampal formation of gestational diabetic and control at 21 postnatal days in rat offspring.

\begin{tabular}{lcc}
\hline \multirow{2}{*}{ Hippocampal formations } & \multicolumn{2}{c}{ P21 } \\
\cline { 2 - 3 } & Control & GD \\
\hline CA1 & $8.16 \pm 1.1$ & $24.72 \pm 2.5$ \\
CA2 & $7.66 \pm 0.8$ & $26.16 \pm 1.9$ \\
CA3 & $5.33 \pm 1.9$ & $23.91 \pm 2.9$ \\
Dentate gyrus & $15.16 \pm 2.2$ & $32.20 \pm 4.1$ \\
\hline
\end{tabular}

Results are expressed as Mean \pm SEM of the mean (*compared with control group, $\mathrm{P}<0.01, \mathrm{n}=6$ ).
Table I. The density of apoptotic cells in hippocampal formation of gestational diabetic and control at 7 postnatal days in rat offspring.

\begin{tabular}{lcc}
\hline \multirow{2}{*}{ Hippocampal formations } & \multicolumn{2}{c}{ P28 } \\
\cline { 2 - 3 } & Control & GD \\
\hline CA1 & $3.5 \pm 2.1$ & $34.12 \pm 1.9$ \\
CA2 & $5.5 \pm 0.7$ & $12.25 \pm 1.2$ \\
CA3 & $7.83 \pm 2.0$ & $31.80 \pm 4.7$ \\
Dentate gyrus & $18.52 \pm 3.1$ & $26.90 \pm 3.7$ \\
\hline
\end{tabular}

Results are expressed as Mean \pm SEM of the mean (*compared with control group, $\mathrm{P}<0.01, \mathrm{n}=6$ ).

TUNEL positive CA1, CA2 and CA3 pyramidal nuclei. In the CA1, in 7, 21 and 28 days offspring, the number of TUNEL-positive nuclei tended to be significantly higher in the gestational diabetic group $(36.81 \pm 1.4,24.72 \pm 2.5$ and $34.12 \pm 1.9$, respectively) compared to the normoglycemic group $(12.83 \pm 1.3,8.16 \pm 1.1$ and $3.5 \pm 2.1$, respectively) $(\mathrm{P}<0.001)$.

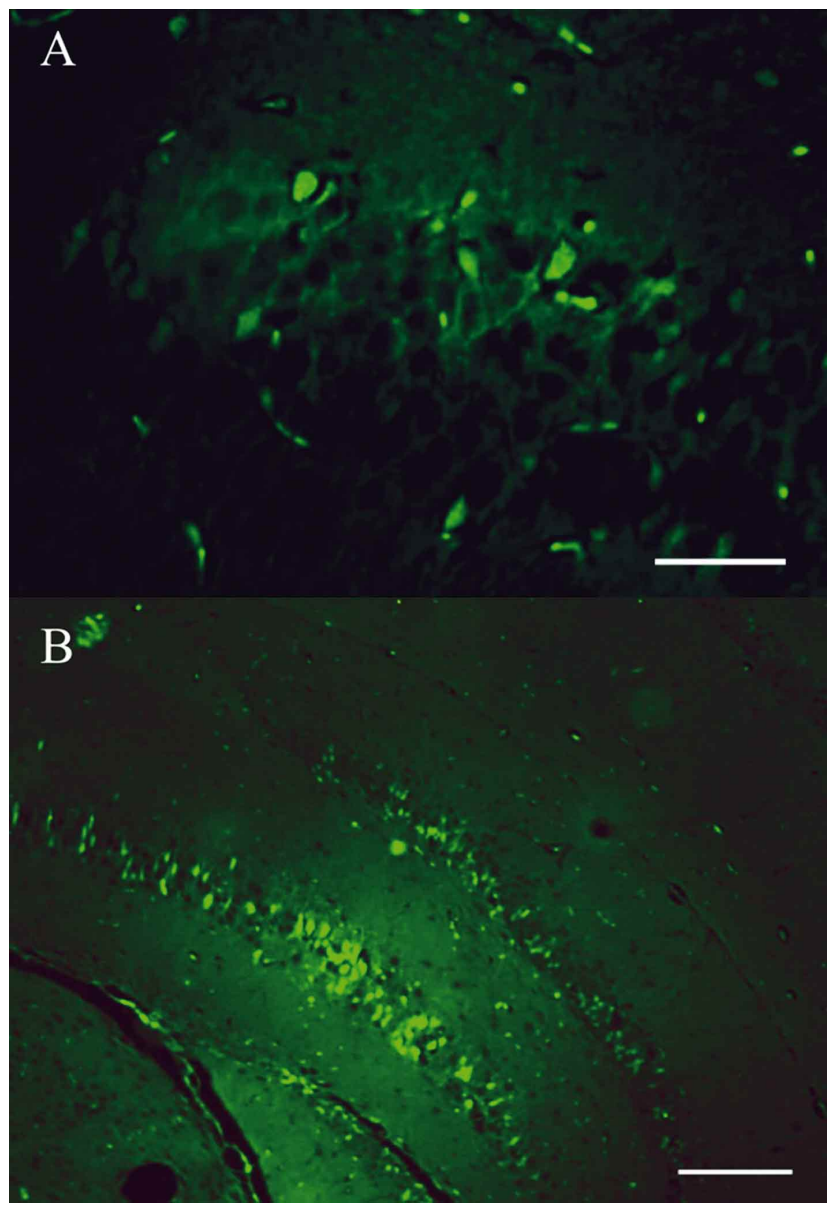

Fig. 1. Representative photomicrographs of TUNEL-positive cells in the CA3 subfield of hippocampus and dentate gyrus at postnatal day 28 (P28) of diabetic offspring. TUNEL-positive cells in A; pyramidal layer of hippocampal CA3 (x400 magnification) and B; granular layer of dentate gyrus (x200 magnification). Scale bars $=100$. 


\section{Hippocampal CA1 subfield}

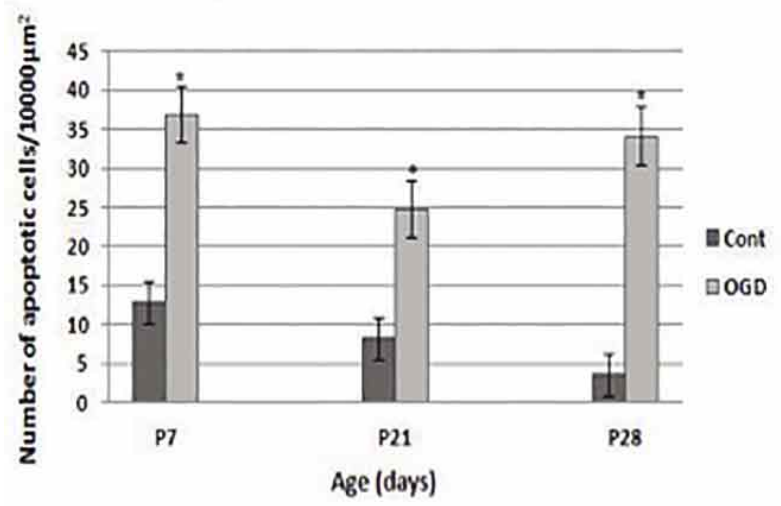

Hippocampal CA3 subfield

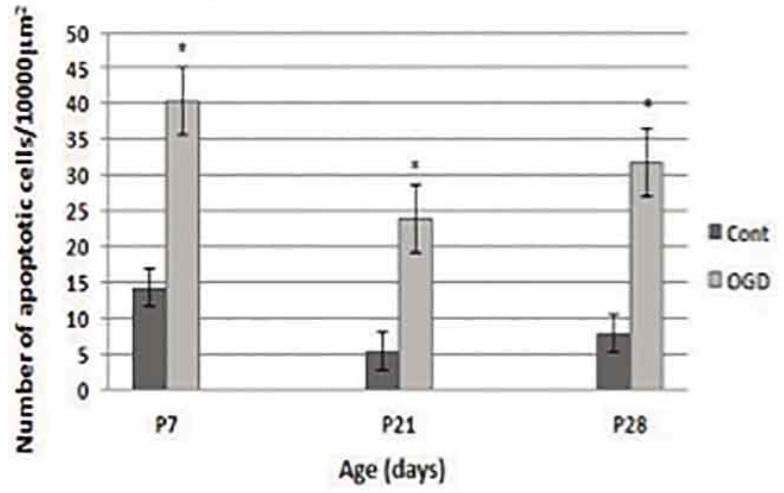

Hippocampal CA2 subfield

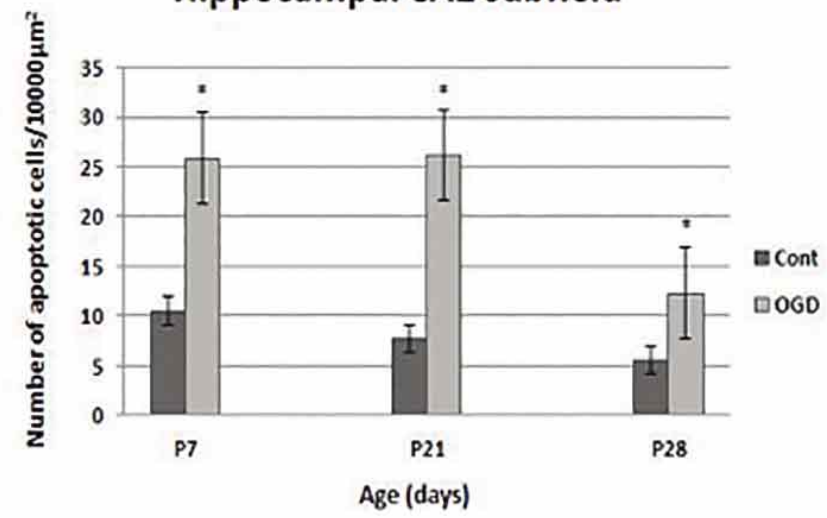

Dentate gyrus (DG)

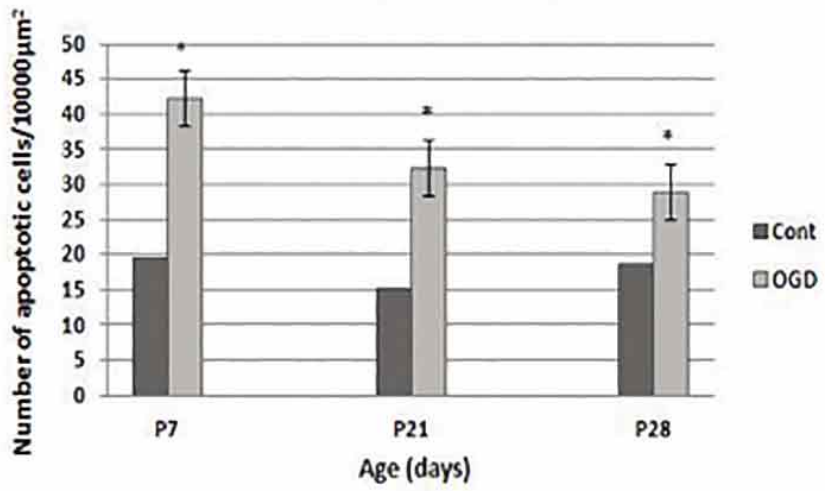

Fig. 2. The density of apoptotic cells in hippocampal formation of gestational diabetic and control in CA1 (a), CA2 (b) and CA3 (c) and dentate gyrus (d) at 7,21 and 28 postnatal days in the rat offspring.

In the CA2, in postnatal day (P7, P21, P28), the number of TUNEL-positive nuclei tended to be significantly higher in the gestational diabetic group $(25.85 \pm 1.6$, $26.16 \pm 1.9$ and $12.25 \pm 1.2$, respectively) compared to the normoglycemic group $(10.50 \pm 0.4,7.66 \pm 0.8$ and 5.5 \pm 0.7 , respectively) ( $\mathrm{P}<0.001)$.

In the CA3, the number of apoptotic cells in P7, P21 and P28were 40.36 $\pm 1.5,23.91 \pm 2.9$ and $31.80 \pm 4.7$ in gestational diabetic group which were significantly increased in compared to controls including 14.16 $\pm 2.1,5.33 \pm 1.9$ and $7.83 \pm 2.0$, respectively $(\mathrm{P}<0.001)$.

TUNEL positive DG granular nuclei. Also, in the dentate gyrus, the incidence of TUNEL-positive nuclei tended to be significantly higher in the offspring of gestational diabetic group compared to the normoglycemic group. The number of apoptotic cells in 7, 21 and 28-day-old offspring were $42.18 \pm 3.6,32.20 \pm 4.1$ and $26.90 \pm 3.7$ in compared to controls including $19.33 \pm 3.1,15.16 \pm 2.2$ and $18.52 \pm 3.1$, respectively $(\mathrm{P}<0.01)$.

\section{DISCUSSION}

This study by TUNEL Assay demonstrated that gestational diabetes produces a significant increase of apoptotic cell density in CA1, CA2 and CA3 hippocampal subfields and dentate gyrus in the postnatal 7, 14 and 21 days of Wistar rats.

The finding of this study is similar to previous studies which were done in various parts of brains in the induced diabetes animals except induced gestational diabetes (Magariños \& McEwen; Li et al., 2002a, 2002b; Klein \& Waxman; Ahmadpour \& Haghir; Britton et al.; Grillo et al.; Russell \& Feldman, 1999).

Li et al., study showed that $34 \%$ of CA1 neurons reduced after 8 months of induction of type I diabetes and increased apoptotic cells in the sub-granular zone of the dentate gyrus (Li et al., 2002a, 2002b). Russell \& Feldman study in a culture model showed that increase of glucose 
level increase Caspase 3 and induces apoptosis in sympathetic neurons. Ahmadpour \& Haghir in animal model study showed that type I diabetes reduces dark neurons in the dentate gyrus by increasing apoptosis. Grillo et al. reported that hyperglycemia increase extracellular glutamate in CA3 and apoptosis in rat hippocampus. Britton et al. by TUNEL Assay in animal model study reported the increasing of apoptotic cell in the peroptic and parietal cortex of induced diabetic rats. Klein \& Waxman in animal model study have shown that diabetes induced enzymes alterations, apoptosis and finally cell death in hippocampal neurons and in chronic hyperglycemia reduced insulin like growth hormone and causes apoptosis in hippocampal neurons. In addition, Magariños \& McEwen study showed that type 1 diabetes induced neuronal apoptosis in pyramidal layer of CA3 subfield of hippocampus.

Apoptosis in neuronal cell can induce by several mechanisms: i) One mechanism can be due to increase Caspase 3 in hippocampal neurons. Caspase 3 is a protein that grouped in apoptosis promotional factor in the cells ( $\mathrm{Li}$ et al., 2002a, 2002b). ii) Another mechanism of Apoptosis in neuronal cell can be due to increase of extracellular glutamate due to defect in NA/K pump (Magariños \& McEwen; Grillo et al.).

Moreover, insulin-like growth factor has a neuroprotective and anti-apoptotic effect and down regulation of expression of insulin-like growth factor and its receptor in diabetes can be expected to lead to neuronal loss due to apoptosis and cell death (Klein \& Waxman; Li et al., 2002a, 2002b).
Diabetes mellitus is a chronic endogenous stressor that is associated with increased oxidative stress in central nervous system (Ahmadpour et al., 2010; Grillo et al.). CNS complications of diabetes mellitus could be mediated through excessive free radicals generation (Ahmadpour \& Haghir; Ahmadpour et al., 2008; Okouchi et al., 2005; Ziegler et al., 2004). Free radicals cause mitochondrial alterations and activated apoptosis by caspase pathways (Russell \& Feldman).

Indeed, other possible mechanism in cause of program cell deaths in diabetes mellitus (Allen et al., 2005; Arroba et al., 2003, 2005, 2007; Klein et al., 2004; Lechuga-Sancho et al., 2006a, 2006b) can be due to insulin decrease or insulin-like growth factor signaling (Ishii, 1995) or an increase in cytokines such as TNFa (Chen \& Goeddel, 2002).

\section{CONCLUSION}

This study using TUNEL Assay showed the uncontrolled gestational diabetes induces neuronal apoptosis in the CA1, CA2, CA3 subfield of hippocampus and dentate gyrus in rat offspring.

\section{ACKNOWLEDGEMENTS}

For funding, we thank the Deputy research of Golestan University of Medical Sciences for financial support (Grant number: 35-1102).

GHAFARI, S.; ASADI, E.; SHABANI, R. \& GOLALIPOUR, M. J. Apoptosis neuronal del hipocampo en crías de ratas debido a la diabetes gestacional. Int. J. Morphol., 34(1):205-211, 2016.

RESUMEN: La diabetes mellitus gestacional (DMG) se define como la intolerancia a la glucosa que afecta aproximadamente al $6 \%$ de todas las mujeres embarazadas que nunca han tenido diabetes, pero que sí tienen niveles de glucosa en la sangre elevados durante el embarazo. El objetivo de este estudio fue evaluar la apoptosis de células neuronales en CA1, CA2 y CA3, subcampos del hipocampo y el giro dentado, en las crías de ratas con diabetes gestacional en los días 7, 21 y 28 luego del nacimiento. Se utilizaron 30 ratas Wistar asignadas aleatoriamente en grupos control y diabético (GDM). Se administró al grupo diabético $40 \mathrm{mg} / \mathrm{kg}$ de peso corporal de estreptozotocina en el primer día de gestación y el grupo control recibió un volumen equivalente de solución salina normal por inyección vía intraperitoneal. Seis crías de los grupos GDM y control fueron seleccionadas aleatoriamente y sacrificadas bajo anestesia los días 7 , 21, 28. Se tomaron secciones seriales coronales del cerebro. La apoptosis neuronal se evaluó mediante ensayo TUNEL. En el CA1, el número de células apoptóticas a los 7, 21 y 28 d se incrementó significativamente en el grupo GDM en comparación con los controles (P $<0.001)$. En el CA2 y CA3 el número de células apoptóticas en los días 7, 21 y 28 también se incrementó significativamente en GDM en comparación con los controles ( $\mathrm{P}<0,001)$. En el giro dentado, el número de células apoptóticas en los días 7, 21 y 28 se incrementó significativamente en GDM en comparación con los controles ( $\mathrm{P}<0,01)$. Este estudio mostró que la diabetes gestacional no controlada aumenta significativamente la apoptosis neuronal en el hipocampo y el giro dentado en las crías de las ratas.

PALABRAS CLAVE: Diabetes gestacional; Hipocampo; Neurona; Apoptosis; Ensayo TUNEL; Giro dentado; Rata. 


\section{REFERENCES}

Ahmadpour, S. H. \& Haghir, H. Diabetes mellitus type 1 induces dark neuron formation in the dentate gyrus: a study by Gallyas' method and transmission electron microscopy. Rom. J. Morphol. Embryol., 52(2):575-9, 2011.

Ahmadpour, S.; Sadeghi, Y. \& Haghir, H. Streptozotocin-induced Hyperglycemia Produces Dark Neuron in CA3 Region of Hippocampus in Rats. Asian J. Med. Sci., 2(1):11-5, 2010.

Ahmadpour, S.; Sadegi, Y. \& Haghir, H. Volumetric study of dentate gyrus and CA3 regions in hippocampus of streptozotocin-induced diabetic rats: Effect of insulin and ascorbic acid. Iran. J. Pathol., 3(1):1-4, 2008.

Allen, D. A.; Yaqoob, M. M. \& Harwood, S. M. Mechanisms of high glucose-induced apoptosis and its relationship to diabetic complications. J. Nutr. Biochem., 16(2):705-13, 2005.

Arroba, A. I.; Frago, L. M.; Argente, J. \& Chowen, J. A. Activation of caspase 8 in the pituitaries of streptozotocininduced diabetic rats: implication in increased apoptosis of lactotrophs. Endocrinology, 146(10):4417-24, 2005.

Arroba, A. I.; Frago, L. M.; Pañeda, C.; Argente, J. \& Chowen, J. A. The number of lactotrophs is reduced in the anterior pituitary of streptozotocin-induced diabetic rats. Diabetologia, 46(5):634-8, 2003.

Arroba, A. I.; Lechuga-Sancho, A. M.; Frago, L. M.; Argente, J. \& Chowen, J. A. Cell-specific expression of X-linked inhibitor of apoptosis in the anterior pituitary of streptozotocin-induced diabetic rats. J. Endocrinol., 192(1):215-27, 2007.

Artola, A. Diabetes-, stress- and ageing-related changes in synaptic plasticity in hippocampus and neocortex--the same metaplastic process? Eur. J. Pharmacol., 585(1):153-62, 2008.

Biessels, G. J.; van der Heide, L. P.; Kamal, A.; Bleys, R. L. \& Gispen, W. H. Ageing and diabetes: implications for brain function. Eur. J. Pharmacol., 441(1-2):1-14, 2002.

Britton, M.; Rafols, J.; Alousi, S. \& Dunbar, J. C. The effects of middle cerebral artery occlusion on central nervous system apoptotic events in normal and diabetic rats. Int. J. Exp. Diabesity Res., 4(1):13-20, 2003.

Cameron, H. A. \& Gould, E. Adult neurogenesis is regulated by adrenal steroids in the dentate gyrus. Neuroscience, 61(2):203-9, 1994.

Chen, G. \& Goeddel, D. V. TNF-R1 signaling: a beautiful pathway. Science, 296(5573):1634-5, 2002.
Gao, Q. \& Gao, Y. M. Hyperglycemic condition disturbs the proliferation and cell death of neural progenitors in mouse embryonic spinal cord. Int. J. Dev. Neurosci., 25(6):349-57, 2007.

Gispen, W. H. \& Biessels, G. J. Cognition and synaptic plasticity in diabetes mellitus. Trends Neurosci., 23(11):542-9, 2000.

Golalipour, M. J.; Kafshgiri, S. K. \& Ghafari, S. Gestational diabetes induced neuronal loss in CA1 and CA3 subfields of rat hippocampus in early postnatal life. Folia Morphol. (Warsz), 71(2):71-7, 2012.

Gould, E. \& Gross, C. G. Neurogenesis in adult mammals: some progress and problems. J. Neurosci., 22(3):619-23, 2002.

Gould, E.; Tanapat, P.; Rydel, T. \& Hastings, N. Regulation of hippocampal neurogenesis in adulthood. Biol. Psychiatry, 48(8):715-20, 2000.

Gould, E. \& Tanapat, P. Lesion-induced proliferation of neuronal progenitors in the dentate gyrus of the adult rat. Neuroscience, 80(2):427-36, 1997.

Grillo, C. A.; Piroli, G. G.; Wood, G. E.; Rezinkov, L. R.; McEwen, B. S. \& Reagan, L. P. Immunocytochemical analysis of synaptic proteins provides new insights into diabetes-mediated plasticity in the rat hippocampus. Neuroscience, 136(2):477-86, 2005.

Hwang, I. K.; Yi, S. S.; Kim, Y. N.; Kim, I. Y.; Lee, I. S.; Yoon, Y. S. \& Seong, J. K. Reduced hippocampal cell differentiation in the subgranular zone of the dentate gyrus in a rat model of type II diabetes. Neurochem. Res., 33(3):394-400, 2008.

Ishii, D. N. Implication of insulin-like growth factors in the pathogenesis of diabetic neuropathy. Brain Res. Brain Res. Rev., 20(1):47-67, 1995.

Jackson-Guilford, J.; Leander, J. D. \& Nisenbaum, L. K. The effect of streptozotocin-induced diabetes on cell proliferation in the rat dentate gyrus. Neurosci. Lett., 293(2):91-4, 2000.

Kamal, A.; Biessels, G. J.; Duis, S. E. \& Gispen, W. H. Learning and hippocampal synaptic plasticity in streptozotocindiabetic rats: interaction of diabetes and ageing. Diabetologia, 43(4):500-6, 2000.

Kim, H.; Jang, M. H.; Shin, M. C.; Chang, H. K.; Lee, T. H.; Lim, B. V.; Jung, C. Y.; Lee, C. Y.; Kim, E. H. \& Kim, C. J. Folium mori increases cell proliferation and neuropeptide $\mathrm{Y}$ expression in dentate gyrus of streptozotocin-induced diabetic rats. Biol. Pharm. Bull., 26(4):434-7, 2003. 
Klein, J. P.; Hains, B. C.; Craner, M. J.; Black, J. A. \& Waxman, S. G. Apoptosis of vasopressinergic hypothalamic neurons in chronic diabetes mellitus. Neurobiol. Dis., 15(2):221-8, 2004.

Klein, J. P. \& Waxman, S. G. The brain in diabetes: molecular changes in neurons and their implications for end-organ damage. Lancet Neurol., 2(9):548-54, 2003.

Lechuga-Sancho, A. M.; Arroba, A. I.; Frago, L. M.; GarcíaCáceres, C.; de Celix, A. D.; Argente, J. \& Chowen, J. A. Reduction in the number of astrocytes and their projections is associated with increased synaptic protein density in the hypothalamus of poorly controlled diabetic rats. Endocrinology, 147(11):5314-24, 2006a.

Lechuga-Sancho, A. M.; Arroba, A. I.; Frago, L. M.; Pañeda, C.; García-Cáceres, C.; Delgado Rubín de Célix, A.; Argente, J. \& Chowen, J. A. Activation of the intrinsic cell death pathway, increased apoptosis and modulation of astrocytes in the cerebellum of diabetic rats. Neurobiol. Dis., 23(2):290-9, $2006 b$.

Li, Z. G.; Zhang, W. \& Sima, A. A. C-peptide prevents hippocampal apoptosis in type 1 diabetes. Int. J. Exp. Diabetes Res., 3(4):241-5, 2002a.

Li, Z. G.; Zhang, W.; Grunberger, G. \& Sima, A. A. Hippocampal neuronal apoptosis in type 1 diabetes. Brain Res., 946(2):221-31, 2002b.

Lim, B. V.; Shin, M. C.; Jang, M. H.; Lee, T. H.; Kim, Y. P.; Kim, H. B.; Lee, K. S.; Kim, H.; Kim, E. H. \& Kim, C. J. Ginseng radix increases cell proliferation in dentate gyrus of rats with streptozotocin-induced diabetes. Biol. Pharm. Bull., 25(12):1550-4, 2002.

Magariños, A. M. \& McEwen, B. S. Experimental diabetes in rats causes hippocampal dendritic and synaptic reorganization and increased glucocorticoid reactivity to stress. Proc. Natl. Acad. Sci. U. S. A., 97(20):11056-61, 2000 .

McCall, A. L. The impact of diabetes on the CNS. Diabetes, 41(5):557-70, 1992.

Okouchi, M.; Okayama, N. \& Aw, T. Y. Differential susceptibility of naive and differentiated PC-12 cells to methylglyoxalinduced apoptosis: influence of cellular redox. Curr. Neurovasc. Res., 2(1):13-22, 2005.

Paxinos, G. \& Watson, C. The Rat Brain in Stereotaxic Coordinates. $4^{\text {th }}$ ed. San Diego, Academic Press, 1998. pp.451.

Revsin, Y.; Saravia, F.; Roig, P.; Lima, A.; de Kloet, E. R.; HomoDelarche, F. \& De Nicola, A. F. Neuronal and astroglial alterations in the hippocampus of a mouse model for type 1 diabetes. Brain Res., 1038(1):22-31, 2005.
Russell, J. W. \& Feldman, E. L. Insulin-like growth factor-I prevents apoptosis in sympathetic neurons exposed to high glucose. Horm. Metab. Res., 31(2-3):90-6, 1999.

Saravia, F. E.; Revsin, Y.; Gonzalez Deniselle, M. C.; Gonzalez, S. L.; Roig, P.; Lima, A.; Homo-Delarche, F. \& De Nicola, A. F. Increased astrocyte reactivity in the hippocampus of murine models of type 1 diabetes: the nonobese diabetic (NOD) and streptozotocin-treated mice. Brain Res., 957(2):345-53, 2002.

Ziegler, D.; Sohr, C. G. \& Nourooz-Zadeh, J. Oxidative stress and antioxidant defense in relation to the severity of diabetic polyneuropathy and cardiovascular autonomic neuropathy. Diabetes Care, 27(9):2178-83, 2004.

\author{
Correspondence to: \\ Dr. Mohammad Jafar Golalipour \\ Gorgan Congenital Malformations Research Center \\ Department of Anatomical Sciences \\ Golestan University of Medical Sciences \\ Gorgan \\ IRAN
}

Phone/Fax: + 98(171) 4425165 / 4421657

Email:mjgolalipour@yahoo.com

Received: 18-08-2015

Accepted: 09-12-2015 